\title{
The Sensorial Structures of Spondylus americanus Hermann,1781 (Mollusca: Bivalvia, Spondylidae)
}

\author{
Marina Gomes Viana ${ }^{1}$ and Cristina de Almeida Rocha-Barreira ${ }^{2}$ \\ ${ }^{1}$ Laboratório de Ecologia de Invertebrados Bentônicos; Fundação Universidade Federal de Rio Grande; Programa \\ de Pós-Graduação em Oceanografia Biológica; C. P: 474; 96201-900; marinagviana@gmail.com; Rio Grande - \\ RS - Brasil. ${ }^{2}$ Laboratório de Zoobentos; Divisão de Oceanografia Biótica; Instituto de Ciências do Mar; \\ Universidade Federal do Ceará; Av. Abolição, 3207; Meireles; 60165-081; Fortaleza - CE - Brasil
}

\begin{abstract}
Adult animals of Spondylus americanus were analyzed and specialized sensorial structures, the sensorial papillae and the eyes, were characterized. The sensorial papillae were projections on the edge of the mantle in form of light brown fingers which had function of percepting stimulus coming from the medium. They were constituted by loose conjunctive tissues with longitudinal muscular fibers and externally covered by ciliated cubic epithelium, which presented high amount of melanocytes that gave the coloration of the papillae. The eyes were more complex, being on small stalks histologically similar to the papillae. They exhibited a circular formate and had a metallic blue color. Theses structures were constituted by a corneo epithelium, cornea, lens, retina, basal stalk, periocular band and optical nerve. The eyes were distributed asymmetrically to both valves related with the sedentarism of the species. Right valve presented a smaller number of eyes when compared to left one.
\end{abstract}

Key words: Mollusca, scallops, eyes, Brazil

\section{INTRODUCTION}

The Spondylidae are bivalves that include big and notable members of coral fauna, rarely occurring in estuary's areas. Acordding to Rios (1994), in the Brazilian coast Spondylus americanus Hermann, 1781, Spondylus ictericus Reeve, 1856 and Spondylus erinaceus Reeve, 1856 are found. In Spondylidae, the most complex sensorial systems are found. Members of this family have a mantle board from both valves, decorated with structures called visual perception organs. All these structures are integrated with the nervous ganglia and are related with sedentary behavior of the species. Zamponi (1976) exposted that in Chlamys the sensorial organs were also integrated with nervous ganglia and that they both mixed with a neuromotora activity that was possibly related to the behavior that will include a register of memory so interesting as the one in cephalopods.

Considering the lack of information about the morphology and histology of Spondylus americanus, this work studied in detail the sensorial organs of this species. (Fig. 1).

\footnotetext{
${ }^{*}$ Author for correspondence
} 


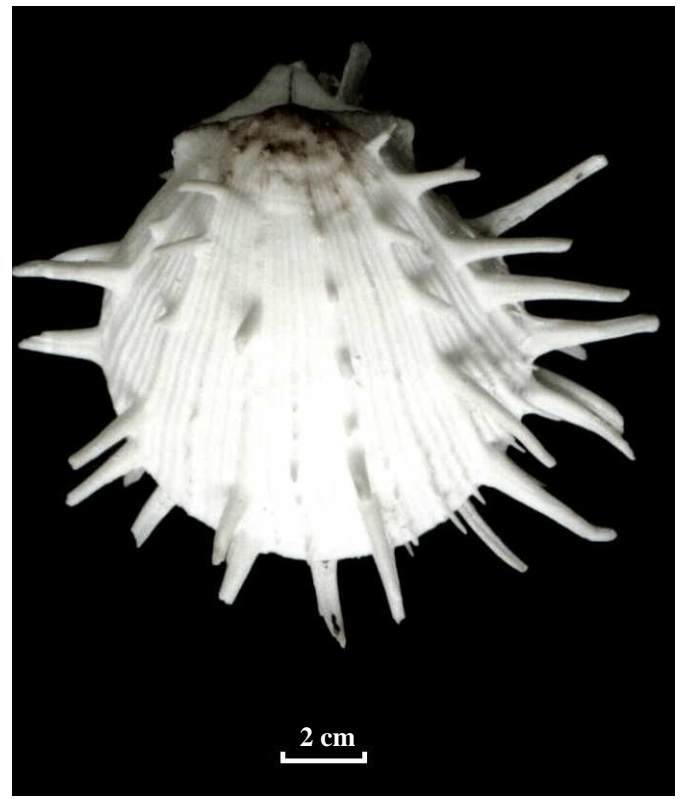

Figure 1 - External view of Spondylus americanus Hermann, 1781

\section{MATERIAL AND METHODS}

Animals of Spondylus americanus were obtained through bottom drags captured by the B.Pq. Prof. Martins Filho from the Instituto de Ciências do Mar of Universidade Federal do Ceará (Brazil) at depth from 10 to $30 \mathrm{~m}$. The specimens from the experimental culture areas at Praia do Pecém-CE were also examined. The organisms used in the anatomic study were fixed in formaline $(10 \%)$ for $24 \mathrm{~h}$ and then preserved in alcohol (70\%).

Observations and characterizations of the structures were made with the help of an stereomicroscop connected to the camera. Organisms used at the histologycal study were fixed in Bouin's saline solution for $12 \mathrm{~h}$ and preserved in alcohol $70 \%$ later on. The histological procedure followed dehydration by alcohol and cleared in xylen, until the inclusion in paraffin. The cross sections (5 to $7 \mathrm{~mm}$ thick) were stained with Harris'hematoxilin and 1\% aqueous eosin (H-E) (Junqueira \& Junqueira, 1983).

\section{RESULTS}

The sensorial papillae and the eyes are structures specialized in the perception of stimulus. In Spondylus americanus, these structures were anatomically arranged in the anterior and posterior board of the mantle. (Fig. 2). 


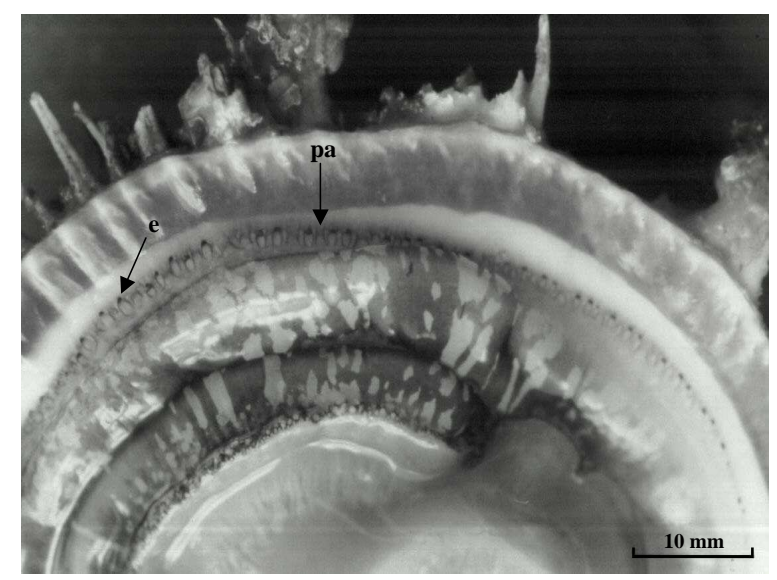

Figure 2 - Photography showed the sensorial papillae (pa) and eyes (e) of Spondylus americanus.

These photoreceptive structures presented sensitive cells, nervous cells and sensorial pigmented elements.

The papillae were projections on the edge of the mantle, like the shape of fingers. Histologically, they were constituted by the connective tissue with longitudinal muscular fibers and were covered by an external ciliated cubic epithelium and presented ganglionary formation. The papillae epithelium appeared to be a continuation of the tissue which covered the mantle. In that area, a great number of melanocytes, responsible for the brownish color of the papillae, were observed (Fig. 3).

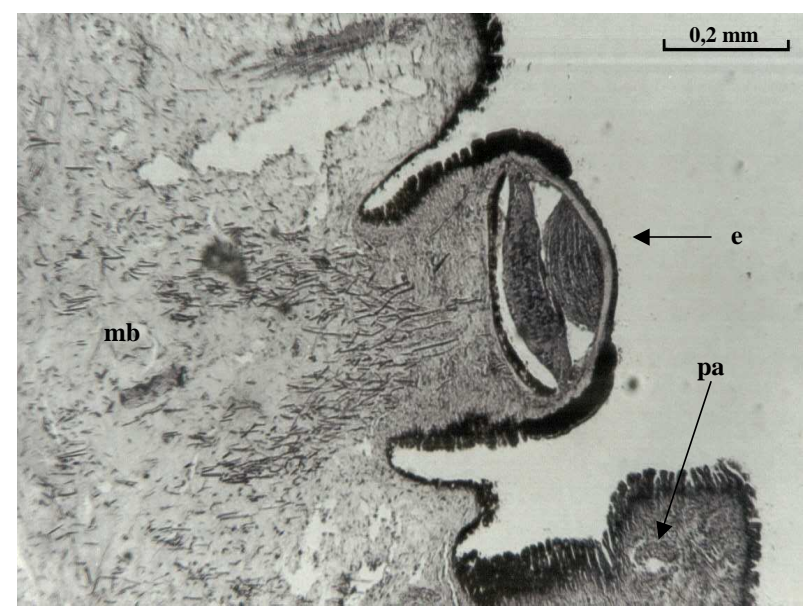

Figure 3 - Transversal section of mantle board $(\mathrm{mb})$ showed the sensorial papillae (pa) and the eye (e). (100x)

In $S$. americanus, the eyes distribution was asymmetrical for both valves and followed the format and size of the shell. The right valve, which stayed in permanent contact with the substratum, presented less number of eyes when compared with the left, superior valve. Organisms with greater size presented a greater number of eyes.
The eyes were very complex and found on small stalks histologically similar to the sensorial papillae. They were spherical, had a blue metallic color and were constituted by an optic capsule that contained the cornea epithelium, lens or crystalline, retina, ocular peduncle, periocular band, optic nerve and a layer of pigment cells (Fig. 4). 
The cornea was formed by a simple and narrow cubic epithelium and was translucent. It was covered externally by the apical area of the ocular globe and showed as a continuity of the epithelium that covered the eye. Below the corneo epithelium, a fine eosinofile acelular layer was present. The cornea epithelium was a discoid structure of cubical cells with the spherical nucleus on the central area. The limits of this epithelium were established by another one pigmented that covered the lateral portions of the optic capsule called periocular band.

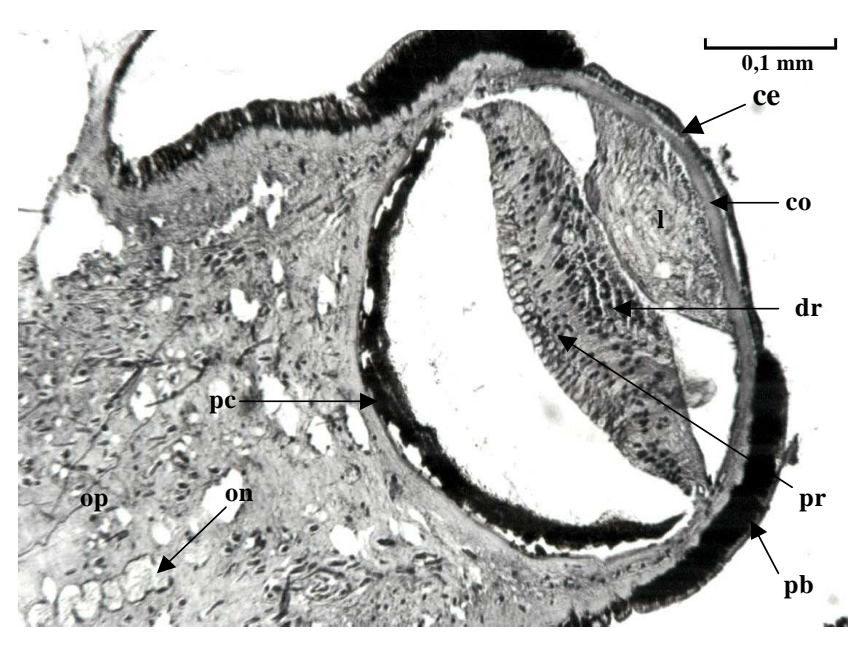

Figure 4 - Transversal section of Spondylus americanus's eyes (200x). Ocular peduncle (op), cornea epithelium (ce), lens (l), distal retina (dr), proximal retina (pr), periocular band $(\mathrm{pb})$, optic nerve (on) and a layer of pigment cells (pc)

The periocular band was formed by prismatic cells and sufficiently compact. These cells presented a high concentration of melanocytes, which were responsible for the strongest pigmentation of the eye. The lens or crystalline were a biconvex body that took half of the optic capsule up. It was constituted by the polyhedral cells with irregular form, eccentric nucleus and acidophilic citoplasmatic granules. The retina was a convex structure that occupied the central portion of the optic capsule. It was formed by two distinct areas: the distal retina and the proximal retina.

The proximal retina was formed by a stratified layer of cubical cells with a limited cytoplasm, big spherical nucleus and very pointed nucleolus. The distal retina was formed by a pseudostratified layer of prismatic cells with nucleus very pointed, below these structures and recovering pigment cells. The ocular peduncle was formed by the connective tissue and diffuse muscular fibers that had the function of uniting and supporting the space between the mantle and the ocular globe. It was covered by the simple prismatic epithelium containing a great number of melanocytes. There were two functional structures inserted in the body of the peduncle: a peduncular ganglia and an optic nerve in the middle of the peduncle.

\section{DISCUSSION}

The histological characteristics that Spondylus americanus presented were sufficiently similar to the standard described to Pectinacea by diverse authors (Ciocco, 1998 and Zamponi, 1976).

The main difference observed was the presence of an eosinophilic acelular layer below the corneo epithelium which was not described for 
other species. This structure, apparently, seems to be related to support of the optic capsule.

The crystalline in $S$. americanus differs from that observed by Ciocco (1998), in Chlamys tehuelchus, and for the others pectinacea (Beninger \& Le Pennec, 1991; Wilkens, 1991) because it did not present integrally sticked with the distal retina.

The lateral spaces found between the crystalline and the retina were similar to the described for Pecten maximus and Chlamys operculari by Dakin (1909).

According to Dakin (1909; 1910a), the space between the retina and the floor of the optic capsule can be attributed to the fixation processes and histological processing. In vivo, the proximal retina and the layer of pigmented cells that covers the floor of the optics capsule were continuos.

The asymmetrical distribution in the number of eyes, in the edge of the mantle, on both valves, observed in $S$. americanus was due to a difference in the relative size of the lateral lobes of viscero-parietal ganglia and the statoreceptors, which was typical in species with inequivalves that presented a defined position of the valves in relation to the substractum (Ciocco, 1998). This standard was observed also in Pecten maximus by Ciocco (1998). The asymmetry in the number of eyes could also be related with the size of valves of this organism.

\section{ACKNOWLEDGMENTS}

The authors wish to express their gratitude to Aline Fernandes Alves de Lima and Maria Lúcia Rodrigues Araújo for helping in the histological process; to Manta Dive and Projeto Netuno for providing animals for the study; to the Daniel Amorim Oriá Fernandes and Fernanda Araújo Paes for reading this manuscript.

\section{RESUMO}

Foram examinados exemplares adultos de Spondylus. americanus Hermann, 1781 e estruturas especializadas na percepção de estímulos foram caracterizadas: as papilas sensoriais e os ocelos. As papilas sensoriais são projeções do bordo manto em forma de dedos de cor castanha e com a função de perceber estímulos vindo do meio, são constituídas por tecido conjuntivo frouxo contendo fibras musculares longitudinais e revestidas externamente por epitélio cúbico ciliado, o qual apresenta grande quantidade de melanócitos, que dão a coloração das papilas. Os ocelos são mais complexos, estando sobre pequenos pedúnculos histologicamente semelhante às papilas, têm formato circular e possui cor azul metálica. Constituí-se por um epitélio córneo, córnea, lente, retina, pedúnculo basal, banda periocular e nervo óptico. Os ocelos distribuem-se assimetricamente por ambas as valvas, o que está relacionado com o sedentarismo da espécie. A valva direita apresenta menor número de ocelos quando comparada a esquerda.

\section{REFERENCES}

Beninger P. G. \& Le Pennec M. (1991), Functional anatomy of scallops. In-Scallops: Biology, Ecology and Aquaculture, ed. S. Shumway. Elsevier Publ. Co., Amsterdam y Nueva York, pp.133-223.

Ciocco, N. F. (1998), Anatomía de la "vieira tehuelche", Aequipecten tehuelchus (=Chlamys tehuelcha). IV. Sistema nervioso y estructuras sensoriais (Bivalvia, Pectinidae) Revista de Biología Marina y Oceanografía 33 (1), 25-42.

Dakin W. J. (1909), The edible scallop. Paper presente at Transactions of the Liverpool Biological Society XVII. 1903, 333-473.

Dakin W. J. (1910a), The eye of Pecten. Quarterly Journal of Microscopical Science 55; 49-112.

Junqueirajunqueira, L. C., Junqueira, L. M. M. S. (1983), Técnicas básicas de citologia e histologia. Livraria e Editora Santos, São Paulo, 123p.

Rios, E. C. (1994), Seashells of Brazil. $2^{\mathrm{a}}$ ed., Editora da Fundação Universidade do Rio Grande, Rio Grande, 492p.

Wilkens, L. A. (1991), Neurobiologia and behaviour of the scallop. In-Scallops: Biology, Ecology and Aquaculture, ed. S. Shumway Elsevier Publ. Co., Amsterdam y Nueva York, pp. 429-469.

Zamponi, M. O. (1976), Estructuras histologicas de las formações oculares de Chlamys tehuelcha (D' Orbigny, 1846) (Pelecipoda, Pectinidae). Revista del Museo de la Plata (Nueva Serie) Sección Zoologia, Tomo XII: 157-165.

Received: January 29, 2005; Revised: March 28, 2006; Accepted: May 15, 2007. 